Jurnal Psikologi Teori dan Terapan

2014, Vol. 5, No. 1, 45-51, ISSN: 2087-1708

\title{
Perbedaan Penyesuaian Pernikahan pada Pasangan yang Menikah Muda
}

\author{
Johan Reny Puspitasari ${ }^{1}$ dan Satiningsih \\ Program Studi Psikologi Universitas Negeri Surabaya
}

\begin{abstract}
Young marriage is vulnerable to many marital problems that can lead to divorce. This study aims to examine the differences of marital adjustment on young married couples considering to 3 marriage reasons, namely (1) their own desires; (2) premarital pregnancy; and (3) matchmaking. Method used in this study was a quantitative comparative research. Data colleced using a scale of marital adjustment which is adapted from Spanier's DAS (Dyadic Adjustment Scale) and analyzed using (1) Kruskal Wallis, and (2) Mann-Whitney. Based on Kruskal Wallis test, the analysis shows the value of sig $0.000(<0.05)$ which means that the hypothesis of this study which states that there is a significant difference of marital adjustment among young married couples in the three reasons based-groups is accepted. In addition, MannWhitney test shows following results: (1) there is a significant difference of marital adjustment between young married couples by their own desires and by premarital pregnancy (sig $0.000<0.05$ ); (2) so Ho is rejected and Ha is accepted which means there is a significant difference of marital adjustment between young married couples by their own desires and by matchmaking process (sig $0.007<0.05$ ); (3) there is a significant difference of marital adjustment between young married couples by premarital marriage and by matchmaking process (sig $0.019<0.05$ ).
\end{abstract}

Keywords: marital adjustment, young married, marriage reasons.

\begin{abstract}
Abstrak: Pernikahan muda sangat rentan terhadap berbagai permasalahan yang dapat berdampak pada perceraian. Penelitian ini bertujuan untuk menguji perbedaan penyesuaian pernikahan pada pasangan yang menikah muda berdasarkan 3 alasan menikah yaitu (1) atas keinginan sendiri, (2) karena kehamilan Pra-nikah, dan (3) karena perjodohan. Metode penelitian yang digunakan adalah penelitian kuantitatif komparatif. Data dikumpulkan menggunakan skala penyesuaian pernikahan yang di adaptasi dari DAS (Dyadic Adjustment Scale) milik Spanier. Teknik analisis data yang digunakan dalam penelitian ini ada 2 yaitu (1) Kruskal Wallis, (2) Uji Mann-Whitney. Berdasarkan hasil uji Kruskal Wallis, diperoleh Sig 0.000 atau <0.05. Ini menunjukkan bahwa ada perbedaan yang signifikan pada penyesuaian pernikahan pada pasangan yang menikah muda atas keinginan sendiri, karena kehamilan pranikah, dan melalui proses perjodohan. Sedangkan dari hasil uji Mann-Whitney, diperoleh, (1) Sig 0.000 atau $<0.05$, artinya ada perbedaaan yang signifikan pada penyesuaian pernikahan antara pasangan yang menikah muda atas keinginan sendiri dengan yang menikah muda karena kehamilan, (2) Sig 0.007 atau $<0.05$, artinya ada perbedaan yang signifikan pada penyesuaian pernikahan antara pasangan yang menikah muda atas keinginan sendiri dengan yang menikah melalui proses perjodohan, (3) Sig 0.019 atau $<0.05$, artinya ada perbedaan yang signifikan pada penyesuaian pernikahan antara pasangan yang menikah muda karena kehamilan pranikah dengan yang melalui proses perjodohan.
\end{abstract}

Kata kunci: penyesuaian pernikahan, menikah muda, alasan menikah.

Korespondensi tentang artikel ini dapat dialamatkan kepada Johan Reny Puspitasari melalui email:reny_psikologi07@ymail.com 
Masalah mengenai menikah muda begitu marak dibicarakan, baik di mediamedia massa maupun forum-forum di internet. Berdasarkan hasil survei yang dilakukan oleh Badan Pusat Statistik (BPS) provinsi Jawa Timur selama tahun 2009, setidaknya terdapat 24.342 remaja perempuan yang telah menikah di usia muda atau sekitar $10,51 \%$ dari total remaja perempuan usia $<20$ tahun di Surabaya (BPS, 2010).

Arti dari pernikahan sendiri menurut undang - undang pernikahan no 1 tahun 1974 adalah ikatan lahir batin antara seseorang pria dan seorang wanita sebagai seorang suami istri dengan tujuan membentuk keluarga yang bahagia dan kekal berdasar Ketuhanan yang Maha Esa. Menurut Sampoerna dan Azwar (1987), pernikahan dini adalah hubungan interaksi secara intim yang diakui secara sosial dan terjadi pada masa pertumbuhan anak menjadi dewasa. Masa terjadinya perkembangan seksual atau masa dalam kehidupan yang dimulai dengan timbulnya sifat seks sekunder yang pertama sampai akhir pertumbuhan somatik. Sehingga seseorang yang dikatakan menikah muda adalah seorang perempuan yang menikah di usia kurang dari 20 tahun dan seorang laki-laki yang menikah sebelum usia 25 tahun.

Gurmu dan Etana (2005) dalam sebuah penelitiannya yang mengungkapkan pernikahan dini, dapat menyebabkan kerentanan pada masa kehamilan dan keberlanjutan pernikahan itu. Seorang perempuan yang menikah atau hamil di usia sebelum 20 tahun dan lebih dari 30 tahun memiliki resiko yang lebih besar dalam proses melahirkannya (Mufidah, 2008). Seseorang perempuan yang menikah muda akan memiliki waktu luang atau bersantai yang lebih sedikit, apalagi setelah mereka menjadi seorang ibu (Borg \& Clark, 1974).

Menurut Soekarno (2005) ada tiga jenis pernikahan muda yang banyak terjadi di Indonesia berdasarkan latar belakang atau alasan mengapa seseorang memutus- kan untuk menikah muda, yaitu: pernikahan yang sudah direncanakan atau atas keinginan sendiri, pernikahan karena kehamilan pra-nikah, dan yang terakhir adalah pernikahan muda yang terjadi karena proses perjodohan. Menurut Hurlock (1991), latar belakang untuk menikah dapat mempengaruhi stabilitas pernikahan. Orang yang terpaksa menikah karena pasangan wanitanya telah mengandung (kehamilan pra-nikah), kemungkinan untuk bercerai jauh lebih besar dari pada pernikahan biasa.

Menikah adalah salah satu dari tugas perkembangan individu. Tetapi kecenderungan menikah muda menyebabkan persiapan perkawinan merupakan tugas perke-mbangan yang paling penting dalam tahun-tahun remaja, karena menurut tugas perkembangan, seharusnya mereka menikah dan mulai membina rumah tangga pada masa dewasa awal (Hurlock, 1991). Pasangan yang menikah di usia muda, usia belasan tahun atau awal duapuluhan cenderung untuk lebih buruk dalam menyesuaikan diri, sebagaimana nampak dalam tingginya tingkat perceraian di antara orang yang kawin pada usia tersebut (Hurlock, 1991). Hal ini didukung oleh Newman \&Newman (1984) yang menunjukkan bahwa probabilitas perceraian tertinggi (mencapai lima puluh persen) pada tahun-tahun awal pernikahan dan terus meningkat sampai tahun ke empat usia pernikahan.

Angka perceraian yang menimpa keluarga di Surabaya pada tahun 2010 juga cukup tinggi, yaitu sebanyak 823 perkara. Menurut data Kantor Wilayah Kementrian Agama Kota Surabaya, terdapat 13 faktor utama penyebab perceraian di Surabaya, yaitu pernikahan di bawah umur, salah satu pihak tidak bertanggungjawab, faktor ekonomi di rumah tangga, sejarah pernikahan para pihak yang dipaksa oleh orang tua, ketidakharmonisan pribadi, gangguan pihak ketiga, faktor politis, poligami tidak sesuai aturan, krisis akhlak, 
cemburu berlebihan, kekerasan dalam rumah tangga, salah satu pasangan cacat biologis, dan salah satu pihak dijatuhi pidana. Kasus perceraian sebagian besar menimpa rumah tangga yang usia perkawinannya masih sangat muda. Sebesar $56,13 \%$ penggugat cerai berusia antara 20-30 tahun.

Perceraian merupakan kumulasi dari penyesuaian pernikahan yang buruk, terjadi bila antara suami istri sudah tidak mampu lagi mencari cara penyesuaian masalah yang dapat memuaskan kedua belah pihak, serta merupakan pilihan terakhir sebagai cara penyelesaian masalah. Pasangan yang tidak mampu melakukan penyesuaian pernikahan dengan baik dan berlangsung secara terus-menerus akan berakhir pada perceraian. Sebaliknya pasangan yang mampu melakukan penyesuaian pernikahan dengan baik maka pernikahannya akan bertahan (Bell, 1985).

Menurut Spanier (1976), keseluruhan penyesuaian dari sebuah perkawinan merupakan proses yang berkesinambungan setiap saat yang menghadirkan komposisi atau keseimbangan antara elemen-elemen atau dimensi-dimensi dalam penyesuaian pernikahan, yaitu (1) Dyadic Satisfaction yaitu tingkat kepuasan dalam hubungan pernikahan atau kepuasan yang dirasakan oleh masing-masing pasangan dalam hubungan mereka, (2) Dyadic Cohesion yaitu tingkat kedekatan atau perasaan kebersamaan yang dimiliki oleh pasangan suami istri, yang menunjukkan seberapa banyak pasangan melakukan berbagai kegiatan secara bersama-sama menikmati kebersamaan yang ada, (3) Dyadic Consensus yaitu tingkat kesepahaman atau kesepakatan di antara pasangan dalam berbagai masalah dalam pernikahan, (4) Afection Expression yaitu tingkat kesepahaman dalam menyatakan perasaan dan hubungan seks maupun masalah yang ada mengenai hal-hal tersebut. Berangkat dari fenomena-fenomena tersebut, dalam penelitian ini mengkaji perbedaan penye-suaian pernikahan pada pasangan yang menikah muda.

\section{Metode}

Metode penelitian yang digunakan adalah penelitian kuantitatif dengan menggunakan penelitian komparatif yang menguji hipotesis yang mengandung pertanyaan perbedaan pada variabel terikat yang mempengaruhi keberadaan variabel bebas (Hadi, 1986). Dikarenakan penelitian ini hanya berlaku pada subjek-subjek tertentu, jumlah populasi yang tidak pasti serta terbatasnya subjek yang sesuai dengan kriteria populasi, maka teknik sampling yang digunakan adalah purposive sampling. Penelitian ini menggunakan skala penyesuaian pernikahan yang di adaptasi dari Dyadic Adjustment Scale (DAS) yang dikemukakan oleh Spanier. Teknik analisis statistik yang digunakan dalam penelitian ini adalah analisis non-parametrik satu jalur atau sering disebut dengan uji KruskalWallis. Uji Kruskal-Wallis ini digunakan untuk uji hipotesis yang berbunyi "ada perbedaan yang signifikan pada penyesuaian pernikahan pada pasangan yang menikah muda atas keinginan sendiri, karena kehamilan pra-nikah dan melalui proses perjodohan".

Sementara itu digunakan uji MannWhitney (U-Test) untuk uji hipotesis yang berbunyi: (1) ada perbedaan yang signifikan pada penyesuaian pernikahan antara pasangan yang menikah muda atas keinginan sendiri dengan pasangan yang menikah muda karena kehamilan pra-nikah; (2) ada perbedaan yang signifikan pada penyesuaian pernikahan antara pasangan yang menikah muda atas keinginan sendiri dengan pasangan yang menikah muda melalui proses perjodohan; (3) ada perbedaan yang signifikan pada penyesuaian pernikahan antara pasangan yang menikah muda karena kehamilan pra-nikah dengan pasangan yang menikah muda melalui proses perjodohan 


\section{Hasil dan Pembahasan}

Hasil uji Kruskal Wallis menunjukkan Sig 0.000 atau $<0.05$, yang artinya ada perbedaan yang signifikan pada penyesuaian pernikahan pada pasangan yang menikah muda atas keinginan sendiri, karena kehamilan pra-nikah dan melalui proses perjodohan. Hal ini berarti bahwa alasan seseorang dalam melakukan pernikahan muda juga memiliki pengaruh yang kuat terhadap penyesuaian pernikahan pasangan yang menikah muda. Dengan menikah muda kecenderungan untuk terjadi perceraian akan lebih besar karena tidak memiliki dasar yang kuat.

Kurangnya dasar yang kuat ini dapat dilihat dari penyesuaian pernikahan yang kurang baik serta alasan awal ketika pasangan tersebut memutuskan untuk menikah. Seperti yang diungkapkan Hurlock (1991), bahwa saat menikah dan alasan untuk menikah merupakan salah satu kondisi yang dapat mempengaruhi stabilitas pernikahan yang dapat dan saling mengakibatkan perceraian.

Hurlock (1991) menyatakan bahwa pernikahan awal usia belasan dan dua puluhan mempunyai kecenderungan penyesuaian yang buruk daripada penyesuaian yang dilakukan oleh pasangan yang menikah di usia akhir duapuluhan atau awal tigapuluhan. Menurut Spainer (1976), penyesuaian pernikahan dapat pula menjadi suatu pengukuran prediktif mengenai kemungkinan penyesuaian pada masa yang akan datang. Artinya jika pada masa awal pernikahan penyesuaian pernikahannya buruk, maka akan mempengaruhi penyesuaian-penyesuaian selanjutnya akan buruk pula atau bahkan menimbulkan perceraian pada masa yang akan datang. Karena menurut Spanier (1976), penyesuaian pernikahan merupakan suatu proses yang berkesinambungan setiap saat, yang akan berlangsung selama pernikahan.

Hasil uji Mann-Whitney yang pertama menunjukkan Sig 0.000 atau $<0.05$, yang artinya ada perbedaan yang signifikan pada penyesuaian pernikahan antara pasangan yang menikah muda atas keinginan sendiri dengan pasangan yang menikah muda karena kehamilan pra-nikah. Dilihat dari mean, penyesuaian pernikahan pada pasangan yang menikah muda atas keinginan sendiri jauh lebih baik jika dibandingkan pada pasangan yang menikah muda karena kehamilan pra-nikah. Hal ini karena, umumnya pasangan yang menikah muda karena keinginan sendiri memiliki persiapan yang jauh lebih lama dan mantap sebelum memutuskan untuk melangsungkan pernikahan. Sedangkan pada pasangan yang menikah muda karena kehamilan pranikah, mereka tidak memiliki persiapan yang cukup sebelum memutuskan untuk menikah. Dibutuhkan waktu sesingkatsingkatnya untuk segera menikah, sebelum kehamilan tersebut semakin besar. Persiapanpun akhirnya hanya seadanya saja. Persiapan untuk menikah memiliki peran yang besar dalam menentukan penyesuaian pernikahan. Pasangan yang menikah atas keinginan sendiri yang memiliki persiapan pernikahan yang cukup dan mantap akan lebih baik dalam penyesuaian pernikahan jika dibandingkan pasangan yang tidak memiliki cukup persiapan seperti pada pasangan yang menikah muda karena kehamilan pra-nikah. Hal ini sesuai dengan pendapat Hurlock (1991), yang mengungkapkan bahwa penyesuaian pernikahan akan menjadi salah satu masalah yang paling sulit yang harus dialami pasangan muda dan salah satu faktor yang menyumbang terhadap kesulitan dalam penyesuaian pernikahan adalah persiapan yang terbatas untuk menikah dan menikah muda.

Hasil uji Mann-Whitney yang kedua menunjukkan Sig 0.007 atau $<0.05$, yang artinya ada perbedaan yang signifikan pada penyesuaian pernikahan antara pasangan yang menikah muda atas keinginan sendiri dengan pasangan yang menikah muda melalui proses perjodohan. Menurut 
Hurlock (1991), beberapa faktor yang menyumbang terhadap kesulitan dalam penyesuaian pernikahan adalah persiapan yang terbatas untuk pernikahan, menikah muda, pacaran yang dipersingkat serta kurangnya identitas. Hal inilah yang menyebabkan perbedaan penyesuaian pernikahan pada pasangan yang menikah muda atas keinginan sendiri dengan pasangan yang menikah muda karena perjodohan. Pasangan yang menikah muda atas keinginan sendiri memiliki persiapan yang cukup untuk menikah, umumnya mereka juga melalui proses pacaran yang tidak singkat, serta tentu saja telah saling mengenal identitas masing-masing melalui proses pacaran yang telah mereka lakukan, hingga akhirnya pasangan tersebut memutuskan untuk menikah karena mereka telah merasa memiliki kecocokan satu sama lain serta dapat menerima segala kelebihan dan kekurangan masing-masing. Sedangkan pasangan yang menikah muda karena perjodohan umumnya tidak memiliki masa pacaran, bahkan terkadang pertunangan terjadi pada masa kanak-kanak. Pengantin pria dan wanita mungkin baru akan bertemu pada hari pernikahan mereka (Papalia,2008). Sehingga mereka tentu saja kurang mengenal identitas, karakter serta pribadi pasangan masing-masing. Kurangnya pengenalan identitas masing-masing pasangan menyebabkan penyesuaian pernikahan tidak berjalan dengan baik. Karena itulah nilai penyesuaian pernikahan pada pasangan yang menikah muda atas keinginan sendiri lebih besar jika dibandingkan pasangan yang menikah karena perjodohan.

Hasil uji Mann-Whitney yang ketiga menunjukkan Sig 0.019 atau $<0.05$, yang artinya ada perbedaan yang signifikan pada penyesuaian pernikahan antara pasangan yang menikah muda karena kehamilan pranikah dengan pasangan yang menikah muda melalui proses perjodohan. Dilihat dari segi persiapan pernikahan, sebenarnya baik pasangan yang menikah karena keinginan sendiri maupun pasangan yang menikah karena dijodohkan sama-sama kurang memiliki persiapan yang cukup untuk menikah. Karena biasanya proses perjodohan hanya berlangsung singkat, jika kedua belah pihak merasa telah ada kecocokan, maka pelaksanaan pernikahan harus dilakukan secepatnya agar tidak menimbulkan zina. Yang membedakan penyesuaian pernikahan pada pasangan yang menikah muda karena kehamilan pranikah dengan pasangan yang menikah muda karena perjodohan adalah motif yang ada didalamnya. Seperti yang diungkapkan Olson (2003) bahwa pasangan yang menikah karena alasan yang positif mempunyai kesempatan yang lebih besar untuk meraih pernikahan yang kuat daripada pasangan yang menikah dengan alasan negatif. Sehingga pasangan yang menikah muda karena dijodohkan lebih dapat menyesuaikan diri lebih baik, jika dibandingkan pada pasangan yang menikah muda karena kehamilan pra-nikah.

Hasil penelitian ini menunjukkan bahwa pasangan yang menikah muda atas keinginan sendiri memiliki penyesuaian pernikahan terbaik jika dibandingkan pasangan yang menikah muda karena kehamilan pra-nikah dan perjodohan. Hal ini terjadi karena pasangan yang menikah muda atas keinginan sendiri umumnya memiliki waktu yang cukup untuk mempersiapkan pernikahannya. Mereka umumnya juga telah melakukan penyesuaian melalui proses pacaran, sehingga mereka memiliki waktu untuk mengenal satu sama lain. Setelah melalui proses pacaran dan merasa sudah cocok satu sama lain mereka berkomitmen untuk menikah. Komitmen untuk menikah serta untuk masa depan hubungan inilah yang biasanya tidak dimiliki oleh pasangan yang menikah muda karena kehamilan pra-nikah. Hal ini karena mereka yang menikah muda karena kehamilan pranikah, tidak mendasari pernikahan mereka dengan komitmen saat memutuskan untuk menikah, melainkan 
menikah untuk menutupi aib kehamilan pra-nikah tersebut. Komitmen untuk masa depan hubungan memiliki pengaruh terhadap kepuasan dan penyesuaian pernikahan. Hal ini sesuai dengan pernyataan Spanier dan Lewis (dalam Fitriane, 2008), bahwa sebuah perkawinan dengan penyesuaian yang baik sering ditandai dengan tingkat interaksi dan kohesivitas yang tinggi, tingkat perselisihan yang rendah, komitmen yang kuat terhadap hubungan yang sedang berlangsung, terjalinnya komunikasi yang baik serta kemampuan memecahkan masalah yang baik. Pasangan yang menikah muda karena dijodohkan memiliki penyesuaian pernikahan yang cukup baik, walaupun tidak sebaik pasangan yang menikah muda atas keinginan sendiri. Pasangan yang menikah muda karena dijodohkan memang memiliki komitmen saat memutuskan untuk menikah, sehingga memberi pengaruh positif pada penyesuaian pernikahannya, tetapi dilihat dari segi kurangnya persiapan pernikahan serta kurangnya pemahaman atau perkenalan sebelum menikah menyebabkan penyesuaian pernikahannya tidak sebaik pasangan yang menikah muda atas keinginan sendiri. Selanjutnya yang memiliki penyesuaian pernikahan terburuk adalah pasangan yang menikah muda karena kehamilan pra-nikah, hal ini karena kurangnya persiapan pernikahan, pacaran yang dipersingkat, serta tidak adanya komitmen kuat yang mendasari hubungan tersebut. Berdasarkan uraian tersebut dapat dibuat sebuah peringkat penyesuaian pernikahan berdasarkan alasan menikah sebagai berikut:

Tabel 1. Peringkat Penyesuaian Pernikahan Berdasarkan Alasan Menikah

\begin{tabular}{cll}
\hline $\begin{array}{c}\text { Pering- } \\
\text { kat }\end{array}$ & $\begin{array}{c}\text { Alasan Menikah } \\
\text { Muda }\end{array}$ & Hal yang mempengaruhi hasil penyesuaian pernikahan \\
\hline 1 & $\begin{array}{l}\text { Atas keinginan } \\
\text { sendiri }\end{array}$ & $\begin{array}{l}\text { Komitmen kuat terhadap masa depan hubungan, } \\
\text { mempersiapkan pernikahan, alasan positif untuk menikah, } \\
\text { pengenalan yang cukup melalui proses pacaran }\end{array}$ \\
\hline 2 & Karena Perjodohan & $\begin{array}{l}\text { Komitmen kuat terhadap masa depan hubungan, kurangnya } \\
\text { persiapan pernikahan, kurangnya pengenalan identitas, } \\
\text { alasan positif untuk menikah }\end{array}$ \\
\hline 3 & $\begin{array}{l}\text { Karena Kehamilan } \\
\text { Pra-nikah }\end{array}$ & $\begin{array}{l}\text { Kurangnya komitmen terhadap masa depan hubungan, } \\
\text { kurangnya persiapan pernikahan, alasan negatif untuk } \\
\text { menikah, pengenalan yang cukup melalui proses pacaran. }\end{array}$ \\
\hline
\end{tabular}

\section{Simpulan}

Hasil dari penelitian ini menunjukkan bahwa: (1) terdapat perbedaan yang signifikan pada penyesuaian pernikahan pada pasangan yang menikah muda atas keinginan sendiri, karena kehamilan pra-nikah dan melalui proses perjodohan; (2) terdapat perbedaan yang signifikan pada penyesuaian pernikahan antara pasangan yang menikah muda atas keinginan sendiri dengan pasangan yang menikah muda karena kehamilan pra-nikah; (3) terdapat perbedaan yang signifikan pada penyesuaian pernikahan antara pasangan yang menikah muda atas keinginan sendiri dengan pasangan yang menikah muda melalui proses perjodohan; (4) terdapat perbedaan yang signifikan pada penyesuaian pernikahan antara pasangan yang menikah muda karena kehamilan pranikah dengan pasangan yang menikah muda melalui proses perjodohan; (5) pasangan yang memiliki penyesuaian pernikahan terbaik adalah pasangan yang menikah muda atas keinginan sendiri, di urutan kedua adalah yang menikah muda karena dijodohkan, sedangkan pasangan yang menikah muda karena kehamilan pra- 
nikah memiliki penyesuaian pernikahan terburuk jika dibandingkan pasangan yang menikah muda atas keinginan sendiri dan karena perjodohan.

\section{Daftar Pustaka}

Azwar. (2008). Reliabilitas Dan Validitas. Yogyakarta: pustaka pelajar offset

Badan Pusat Statistik (BPS) Jawa Timur. (2010). Hasil Survei Sosial Ekonomi Nasional Tahun 2009 Provinsi Jawa Timur.

Bell, R. R. (1985). Marriage and Family Interaction. Chicago: Dorsey Press.

Borg, Stephanie d\& Clark, Marilyn. (tanpa tahun). Leisure \& Young Married Women in Malta. Journal of World Anthropology, Volume III, Number 1 .

Fitriane, Inanda. (2008). Penyesuaian Pernikahan pada Pasangan yang Beda Agama. Skripsi tidak diterbitkan. Surabaya: Fakultas Psikologi UNAIR.

Gurmu, Eshetu \& Etana, Dula. (2005). Early Marriage and First Birth Interval in Ethiopia: Evidences from EDHS 2005, (online), (http://paa2a0.princeton.edu, diakses 5 Januari 2011).

Hurlock, Elizabeth B. (1991). Psikologi Perkembangan. Jakarta: Erlangga.

Mufidah. (2008). Psikologi Keluarga Islam Berwawasan Gender. Malang: UIN-Malang Press.

Newman, B. M., \& Newman, P. R. (1984). Developmental Through Life: A
Psychosocial Approach. Chicago: Dorsey Press.

Olson, D. H. \& DeFrain, J. (2003). Marriages and Families: Intimacy, Diversity and Srength (Fourth Edition). New York: Mc Graw Hills.

Papalia, D. E., Old, S. W., \& Feldman, R. D. (2008). Psikologi Perkembangan (edisi kesembilan). Jakarta: Kencana.

Primastuti, Sinta Kusuma. (2009). Konflik dalam Perkawinan Akibat Kehamilan Pranikah pada Wanita Jawa di Desa Tulung Rejo, Kecamatan Bumuaji, Kota Batu. Skripsi tidak diterbitkan. Jurusan Bimbingan Konseling dan Psikologi. Fakultas Ilmu Pendidikan. Universitas Negeri Malang.

Soekarno, Inneke Tri. (2005). Studi Perbedaan Strong Marriage pada Pasangan yang Menikah Muda. Skripsi tidak diterbitkan. Surabaya: Fakultas Psikologi UNAIR.

Spanier, Graham B. (1976). Measuring Dyadic Adjustment: New Scales for Assessing the Quality of Marriage and Similar Dyads. Journal of Marriage and The Family, 38 (1), 15-28. 